\title{
TEORI KONFLIK DALAM PERSFEKTIF HUKUM ISLAM: INTERKONEKSI ISLAM DAN SOSIAL
}

\author{
Hayat \\ Fakultas Ilmu Administrasi Universitas Islam Malang \\ Jl. MT. Haryono, 193 Malang, 65144 \\ e-mail: hayat.150318@gmail.com
}

\begin{abstract}
Abstrak. Agama sebagai sebuah ideologi dalam masyarakat diyakini memungkinkan untuk menjadi sebuah paradigma sebagai solusi dalam berbagai konflik. Islam adalah agama yang rahmat li al-ālamīn dalam kehidupan manusia dengan konstruksi penyelesaian konflik sebagai koneksivitas dengan hukum adat (etika, nilai-nilai moral, karakter, dan budaya) dan hukum negara yang notabene muncul dari diskursus hukum Islam. Agama menjadi penyeimbang dari konflik yang muncul dari berbagai indikator, karena Islam merupakan sebuah konsensus hukum yang meliputi berbagai kondisi dan situasi. Agama sebagai upaya penengah dari benturan-benturan sosial dan gesekan-gesekan kepentingan masyarakat. Oleh karena itu, Islam sebagai sebuah prinsip, pengatur tatanan kehidupan manusia menjadi sebuah resolusi dalam pemikiran teori konflik dari beberapa ilmuwan yang menunjukkan sebuah eksistensi Islam didalamnya.
\end{abstract}

Abstract. Religion as an ideology in society is believed to allow it to become a paradigm as a solution to conflicts. Islam is a rahmat li al-ālamīn religion in the life of mankind with conflicts settlement construction in the community as connectivity with customary law (ethics, moral values, character, and culture) and state laws that in fact emerged from the discourse of Islamic law. Religion becomes a balancing of social conflicts that arise from a variety of indicators, because Islam is a legal consensus that includes a variety of conditions and situations of society. Therefore, Islam as a principle regulator of human order become a theory of conflict resolution in the minds of some scientists that suggests an existence of Islam in it.

kata kunci: teori konflik. hukum islam, interkoneksi islam dan sosial 


\section{PENDAHULUAN}

Konflik sebagai suatu teori dalam ilmu pengetahuan, membentuk sebuah paradigma baru kehidupan masyarakat yang mencerminkan adanya sebuah pertentangan atau perbedaan dengan berbagai persepsi dan pemahaman terhadap suatu tujuan yang diharapkan. Masyarakat sebagai lembaga sosial tidak terlepas dari benturan-benturan kepentingan yang menimbulkan pelbagai kesalahpahaman dalam berinteraksi, konflik selalu mengiringi kehidupan masyarakat secara universal. Bentuk konflik menjadi sebuah pendewasan untuk berpikir kritis dan peka terhadap keadaan dengan konsep pemikiran yang lebih fleksibel dan akuntabel. Keberadaan konflik ditimbulkan oleh berbagai aliansi yang ada didalamnya, sehingga tidak hanya kepada tataran psikologi dan fisik, akan tetapi konflik juga merambah kepada tatanan kehidupan masyarakat yang sulit terkendali, bahkan konflik agama menjadi pemicu dari gesekan itu sendiri, dengan budaya dendam terhadap konflik menjadi suatu kebiasaan dalam masyarakat modern saat ini.

Penanganan konflik dalam status sosial masyarakat membutuhkan suatu pola yang berbeda dan berimbang sesuai dengan budaya lokal masyarakat yang ada. Hukum islam memberikan sebuah persepsi dalam konflik, dalam hal ini adalah sebuah perbedaan yang memang menjadi katagori normal dalam kajian hukum islam. Perbedaan dalam bermasyarakat menjadi indah jika dilakukan secara islami dengan tidak mengedapankan sebuah egoisme masyarakat. Alquran dan Hadis memberikan pedoman hukum secara islami sebagai sebuah isyarat dalam penanganan konflik kemasyarakatan. Hukum islam memberikan pandangan yang bijak dalam mengendalikan kehidupan masyarakat hingga saat ini sampai pada akhir zaman kelak. Setiap permasalahan dalam kehidupan tentunya ada faktor-faktor yang mempengaruhi sebagai kolaborasi kehidupan manusia yang saling berhubungan satu sama lain dengan berbagai kepentingan dan tujuannya, sehingga konflik didalam kehidupan masyarakat 
menjadi suatu bagian yang melekat. Ketentuan itu merupakan sebuah takdir dalam persfektif hukum islam untuk mengajarkan manusia bagaimana menyelesaikannya dengan pendewasaan secara islami sesuai dengna konsep yang ada dalam Al-Qur'an dan Hadis sebagai pedomana utama untuk menapaki jalan kehidupan yang lebih baik pada hari akhirat kelak.

\section{PEMBAHASAN}

\section{Paradigma Konflik dalalm Teori Ilmu Sosial}

Konflik merupakan sebuah dogma masyarakat terhadap struktural fungsional yang semakin luas dengan pelbagai perbedaan secara substantif dari perubahan dan perkembagan masyarakatt. Keberadaan konflik memberikan ruang kepada seluruh lapisan masyarakat untuk sadar dan mengerti makna dari bermasyarakat, terutama dalam konsep masyarakat modern saat ini, situasi konflik bisa saja terjadi dimana saja, tanpa mengenal ruang dan waktu sesuai dengan keberadaan perbedaan itu sendiri, baik terhadap individu dengan individu, atau individu dengan kelompok atau kelompok dengan kelompok. Kelahirannya ditimbulkan oleh suatu paradigma yang melekat dalam masyarakat bahwa eksistensi individu atau kelompok mempunyai peran lahirnya konflik, terutama dalam mempertahankan keberadaan kelompok tertentu untuk menguasai dan menjadikan kelompok lain untuk dikuasai.

Pandangan dalam menyikapai konflik yang berkaitan dengan perbedaan indentitas menurut sudut pandang kelompok ahli $^{2}$, yaitu: Pertama, pandangan primordialis. Perbedaan-

\footnotetext{
${ }^{1}$ Andik Wahyun Muqoyyiidin. "Potret Konflik Bernuansa Agama di Indonesia; Signifikansi Model Resolusi Berbasis Teologi Transformatif". Analisis, Volume XII, Nomor 2, Desember Tahun 2012. h. 322.

${ }^{2}$ Ramadhanita Mustika Sari, "Jaring Pengaman Pencegah Konflik: Kasus Masyarakat OKU Timur", Tesis, (Jakarta: Sekolah Pascasarjana, Universitas Islam Negeri, 2011), h. 21.
} 
perbedaan genetika seperti suku, ras, dan agama menjadi sumber utama dari sebuah gesekan-gesekan antar kelompok genetik yang mempunyai tujuan-tujuan yang diharapkan dengan kepentingankepentingan yang ada didalamnya, sehingga pada akhirnya terjadi sebuah benturan-benturan yang tidak dapat dihindarkan dengan keinginan untuk tetap eksis dalam diri kelompok itu sendiri. Persfektifnya adalah ketika suatu kelompok merasa dirugikan oleh kelompok lain, maka hal itu menjadi penentu terjadinya sebuah konflik, beberap kasus yang terjadi diberbagai daerah yang sampai hari ini masih menjadi pergulatan antar kelompok yang berkonflik, yang terakhir adalah kasus syiah di sampang yang menjadi sorotan nasional, bahkan hingga internasional. Konflik memang tidak melihat secara realistis, bahwa setiap sesuatu yang bertentangan dengan keberadan lingkungannya yang sudah menjadi nilai-nilai kehidupan.

Kedua, pandangan kaum instrumentalis. Suku, agama dan identitas lainnya merupakan sebuah media untuk mencapai tujuan yang diinginkan, secara material maupun non-material, sehingga segala bentuk keinginan dan tujuan baik individu atau kelompok dalam hal ini merupakan sebuah keharusan untuk menjadikan diskursus yang terus dikembangkan dan ditingkatkan sebagai pemenuhan terhadap capaian yang diharapakan. Oleh karena itu, ketika kelompok dengan tujuan yang diinginkan, maka gesekan dari setiap keinginan kelompok itu menjadi sebuah kewajiban yang harus terus dilakukan. Persinggungannya adalah jika beberapa kelompok dengan tujuan yang berbeda sesuai dengan capaiannya, maka konflik tidak dapat terhindarkan jika capaian itu tidak sesuai dengan harapan, dan menyalahkan kelompok lain sebagai penghambat dari tujuan kelompoknya.

Ketiga, kaun konstruktivis, yang beranggapan bahwa identitas kelompok tidak bersifat kaku, etnisitas bagi kelompok ini dapat diolah hingga membentuk jaringan relasi pergaulan sosial. Kelompok ini berpandangan bahwa semua kelompok etnis dalalm suatu masyarakat adalah sebagai konektivitas untuk 
mencapai tujuan secara bersama dengan konsep jaringan yang dibangun dengan system kerjasama yang saling menguntungkan satu sama lain, serta saling membutuhkan dalam berbagai kegiatan. Sehingga capaian tujuan dari suatu kelompok akan membantu tujuan dari kelompok yang lainnya.

Narwoko, mengungkapkan bahwa konflik antara individu menjadi bagian terpenting dalam ketentraman sosial kemasyarkatan yang rentan terjadi dipelbagai kalangan masyarakat, terutama dalam strata sosialnya, antar kelas atas dan kelas bawah. Hal itu dipicu oleh paradigma yang ada, sehingga perbandingan terhadap status sosial tidak terhindarkan yakni generalized cultural berupa otoritas dan pengetahuan kelas atas yang lebih tinggi dan particularized cultural. Sedangkan konflik peran timbul apabila seseorang harus memilih peranan dari dua atau lebih status yang dimilikinya. Konflik peranan timbul, ketika seseorang merasa tertekan dengan peran yang dimiliknya, dengan persepsi bahwa peran yang disandangnya tidak sesuai dengan status yang dimilikinya, sehingga dalam perjalan peran itu menjadi bagian dari konflik yang menyertainya sebagai konskuensi hirarki dari paradigma yang ada. Akibatnya, ia tidak melaksanakan peranannya dengan ideal. Konflik dalam satu peran, yaitu suatu konflik yang terjadi karena seorang individu dalam waktu yang sama harus melakukan peranan yang berbeda ${ }^{3}$.

Rahayuningiyas dan Sudrajat ${ }^{4}$, dalam penelitiannya mengungkapkan bahwa Collins melalui pendekatan konflik terhadap stratifikasi dapat diturunkan menjadi tiga prinsip. Pertama, bahwa orang hidup dalam dunia subjektif yang dibangun sendiri. Prinsip ini menunjukkan bahwa kehidupan manusia dalam menentukan arah hidupnya ditentukan oleh subyektifitas tujuan hidup yang dibangun melalui perilaku dan

3 Defi Arini Rahayuningtias dan Arief Sudrajat, "Konflik dan Pola Defiance Warga Perwira di Komplek Militer", Jurnal Paradigma, Volume 01, Nomor 03, Tahun 2013, hal. 5-6.

${ }^{4}$ Ibid. hal. 2. 
tingkah lau serta kebiasaan-kebiasaan yang memberikan eksistensi untuk melegitimasi bahwa kehidupannya dibentuk oleh dirinya sendiri, sehingga penguasaan terhadap kepemilikan yang dimilikinya menjadi keharusan untuk dipertahankan dengan segala macam konflik yang menghantui disekitarnya, artinya bahwa, stratifikasi sosial dalam prinsip ini membangun sebuah pola internalisasi sosial kemasyarakatan yang berkaitan langsung dengan individualisme diri manusia itu sendiri, orang lain tidak mempunyai hak untuk mengganggunya dengan cara apapun. Kekuasaan misalnya yang melekat terhadap pembangunan individu ini, cenderung tidak mengindahkan konsep interaksi hubungan manusia dengan manusia lainnya. Ketika ada ketidaknyamanan dengan kepemilikan dirinya, baik yang diakibatkan oleh diri sendiri atau oleh orang lain, maka konflik individu tidak dapat dihindari, sehingga penyelesaiannya perlu diselesaikan secara individu untuk memastikan positif dan negatifnya suatu konflik.

Kedua, orang lain mempunyai kekuasaan untuk mempengaruhi atau mengontrol pengalaman subjektif seorang individu. Dalam kaidah sosisologi, antara masyarakat individu dan masyarakat lainnya mempunyai hubungan desentralisasi dalam ruang masyarakat sebagai konsepsi masyarakat. Masayarakat merupakan sekelompok orang yang berada dalam suatu wilayah untuk menjaga, mengamankan dan membantu antara masyarakat yang membutuhkan dengan interaksi dan budaya serta nilai-nilai didalam norma masyarakat yang berlaku. Kehidupan masyarakat mempunyai tujuan hidup kemasyarakatan yang saling berpengaruh dan mengontrol antara masyarakat yang satu dengan yang lainnya sebagai upaya perbaikan dan perubahan yang sedang dan akan dialami untuk meningkatkan kualitas hidup masyarakat yang lebih baik. Kontrol terhadap masyarakat yang lain berpotensi adanya konflik dari persfektif stratifikasi sosial, dengan paradigma yang dibangun terhadap urusan orang lain yang mengakibatkan kepada hal yang negatif ketika 
seseorang membicarakan orang lain, dengan latar belakang fitnah yang biasa berkembang di masayarkata terhadap pembicaraan yang dilakukan membuat orang lain tidak nyaman, karena fakor yang mempengaruhinya. Hal ini berdampak adanya konflik diantara individu yang mengontrol kehidupan orang lain dalam persfektif apapun dan dengan cara apapun.

Ketiga, orang lain sering mencoba mengontrol orang yang menentang mereka, akibatnya adalah kemungkinan terjadinya konflik individu. Kebiasaan-kebiasaan sebagai kodrat manusia yang mempunyai nilai buruk dan baik dalam kehidupannya menjadi sebuah pertentangan dalam penilaian terhadap orang yang melakukan pertentangan terhadap kekuasaan yang dibangun oleh individu. Membicarakan dan mengkritisi penguasa dalam konsep pemahaman untuk memperbaiki sistemnya, menjadikan sebagai indikator konflik antara idividu. Hal itu akan kembali kepada niat dan tatacara bagaimana individu mengelola pola ketidaksepahaman dalam penerapan interaksinya, sehingga jika konspirasi yang dibangun adalah untuk mematahkan dan melemahkan individu yang lain, maka konflik akan berada ditengah-tengahnya sebagai konskuensi dalam pertentantangannya.

\section{Strategi Penyelesain Konflik; Sebuah Konsepsi Sebagi Solusi}

Lederach secara konstruktif sosial konflik diasumsikan sebagai berikut ${ }^{5}$ : (1) konflik sosial dipahami sebagai hal yang alamiah. Keberadaan konflik ditimbulkan oleh lingkungan alam disekitarnya, dengan berbagai situasi dan keadaan yang muncul dipengaruhi oleh sekelilingnya; (2) konflik dipahami sebagai kejadian konstruktif kebudayaan secara sosial. Perubahan sosial tidak dapat dihindari dengan kondisi zaman yang menuntutnya, secara konstruktif sosial menjadi sebuah pertentangan terhadap

${ }^{5}$ Ibid. Sari, “Jaring Pengamanan................", h. 21-22 
budaya yang ada, sehingga budaya baru yang masuk dalam sebuah konstruksi budaya lama bisa menjadi indikator munculnya sebuah konflik; (3) konflik muncul melalui proses interaktif yang berlandaskan kepada penciptaan dan pencarian tujuan. Tujuan sebagai capaian dari setiap individu atau kelompok menjadi sesuatu yang harus dicapai. Hambatan dalam capaian tujuan sebagai pertentangan dalam diri individu atau kelompok yang berpengaruh terhadap adanya konflik, baik terhadap individu dengan individu, individu dengan kelompok, atau kelompok dengan kelompok; (4) proses interaktif disempurnakan melalui persepsi manusia. Setiap manusia mempunyai pemaknaan tersendiri dari berbagai interaksi yang dibangun didalamnya, perbedaan persepsi dengan yang terjadi terhadap persepsi orang lain merupakan bagian dari timbulnya sebuah konflik; (5) pemaknaan muncul dalam diri manusia sebagai masyarakat sosial dengan berbagai tujuan hidupnya dalam kelompok masyarakatnya; (6) kebudayaan yang berakar dari pengetahuan untuk merasakan, menafsirkan, mengekspresikan, dan merespons realitas sosial. Sebagai suatu budaya lokal yang terus membutuhkan perubahan dalam kehidupan manusia dari berbagai pengetahuan yang dimilikinya dalam memahami secara universal terhadap situasi dan ekspresi yang berkelanjutan; (7) pemahaman hubungan konflik sosial dan budaya terhadap ilmu pengetahuan secara umum.

Konflik juga menjadi biang dari berbagai kerusuhan secara massal dalam kelompok atau lembaga-lembaga masyarakat lainnya, seperti yang terjadi di Maluku Utara antara awal tanun 1999 dan 2005 adalan fluktuasi dan penyebaran kekerasan kolektif. Rentang waktu yang cukup lama dalam proses penyelesaian konflik menjadi asupan dendam lama yang terbangun dengan sendirinya ketika suatu masyarakat tidak menyadari keberadaan konflik dengan merugikan semua pihak, 
bahkan menyebar kebeberapa kelompok lain sebagai fluktuasi dari deretan kompilasi konflik yang terjadi ${ }^{6}$.

John Burton dalam Muqayyiddin ${ }^{7}$ mengatakan bahwa konflik bukanlah watak manusia, akan tetapi sebagai sebuah karakter yang melekat dalam diri manusia sebagai kodrat yang harus dipahami secara universal dan menyeluruh. Konflik diterjemahkan sebagai ketidak terpenuhinya kebutuhan manusia dalam struktur sosial ekonomi sebagai kebutuhan dasar yang melahirkan keberadaan konflik dalam kehidupan sosial masyarakat. John Burton, menambahkan bahwa kebutuhan dasar manusia itu dibagi kedalam dua prinsip. Pertama, Ontological need. Kebutuhan rasa aman yang menjadi bagian terpenting dalam kehidupan manusia. Secara hirarki manusia menginginkan sebuah kehidupan yang tentram, bahagia, selamat dalam menjalankan proses kehidupan serta aman dalam menjalankan segala aktifitasnya. Kebutuhan aman sebagai dasar kebutuhan manusia mempunyai implikasi yang sangat kuat terhadap psikologi manusia dalam bersosialisasi dan bermasyarakat, dengan rasa aman yang dimilikinya menjadi titik tolak dari sebuah kehidupan yang nyaman dan sentosa. Ketika rasa aman individu atau kelompok terganggu oleh orang lain atau kelompok lain, maka konflik tidak dapat dihindarkan dengan variasi teknis yang ada didalamnya, karena ketidakamanan menimbulkan sebuah impact ketidaknyamanan dalam kelompok atau individu tersebut.

Kedua, subjective psicological need. Kebutuhan pengakuan akan eksistensi hidup manusia. Kebutuhan ini tergantung kepada setiap individu atau kelompok dalam merefleksikan dirinya sebagai manusia yang utuh dengan kemampuan dan kelebiahn

\footnotetext{
${ }^{6}$ Lala Mulyowibowo Kolopaking, Djuara Pangihutan Lubis, August Ernest Pattiselanno, "Jejaring Sosial dan Resolusi Konflik Masyarakat di Pedesaan (Kasus di Pulau Saparua Provinsi Maluku)", Jurnal Pertanian Indonesia, Volume 12, Nomor 3, Desember 2007, hal. 189.

${ }^{7}$ Ibid. Muqoyyiidin, "Potret Konflik..............., hal. 321
} 
yang dimilikinya, implikasinya kepada sebuah eksistensi sebagai keharusan yang dipertahankan dan dieksplorasi untuk penguatan dirinya dengan pengakuan yang diberikannya. Eksitensinya bermuara dari rasa dan jiwa yang berada didalamnya untuk diterima dengan berbagai konsepsi yang melekat, sehingga mempertahankan sebuah eksistensi dalam kehidupan sosial masyarakat menjadi suatu kebutuhan yang harus dikembangkan. Setiap manusia lebih suka membicarakan keberadaan dan kelebihan didalam dirinya untuk selalu diungkap dan dipublikasi. Sebagai bahan dasar dalam sebuah kehidupan, eksistensi menjadi sebuah indicator adanya konflik, baik dalam diri individu atau kelompok yang mempunyai pengaruh didalamnya. Ketika eksistensi itu merasa tidak teraplikasikan dalam prosesnya, tentunya konflik melekat dalam ketidakberadaan sebuah kelompok atau individu yang eksis, ketidaksepahaman terhadap keberadaannya menimbulkan efek negative yagn merugikan satu sama lain karena pengakuan yang tidak dikuatkan oleh prinsip penerimaan terhadap keberadaannya.

Den G. Pruit dan Jeffry Z. Rubbin ${ }^{8}$, mengungkapkan bahwa strategi terhadap adanya konflik dari pihak-pihak yang berkonflik. Pertama, contending (bertanding). Sebagai bentuk penyelesaian konflik yang dialami oleh pihak yang berkonflik, langkah contending menjadi bagian yang dapat menyelesaikan keberadaan konflik. Confending adalah penyelesaian konflik dengan cara bertanding atau bertengkar untuk memperebutkan apa yang menjadi konflik, artinya bahwa, perbedaan yagn terjadi dalam pihak-pihak yang berkonflik mempunyai peluang menang atau kalah, hal ini merupakan sebuah konsep yang realistis terjadi di berbagai aspek kehidupan masyarkaat sosial. Ketika pertengkaran sudah usai, maka sudah bisa dipastikan konflik

${ }^{8}$ Den G. Pruit dan Jeffry Z. Rubbin, Teori konflik Sosial, ter. Helly P. Soejtipto dan Sri Mulyantini Soetjipto, (cet. III; Yogyakarta: Pustaka Pelajar, 2011), 4-6. 
dengan sendiri terselesaikan, hanya saja, dalam konsep penyelesaian konflik dengan cara confending ini akan menimbulkan sebuah konflik-konflik baru yang mengikutinya, dengan kata lain, aspke dendam dan balas dendam dalam strategi ini menjadi konflik semakin besar.

Kedua, yielding (mengalah). Perbedaan dalam sosial kemasyarakat menjadi semakin khas dalam kehidupan, semakin tinggi nilai konsumtif masyarakat, keberadaan konflik semakin tinggi pula. mengalah merupakan bagian solusi dari strategi pihak-pihak yang berkonflik. Hal ini merupakan bagian yang mengisyaratkan, bahwa mengalah bukan berarti kalah. Artinya, setiap perbuatan mengalah adalah untuk menghindari konskuensi dari perbedaan yang terus diperdebatkan dalam suatu persoalan. mengalah sebagai solusi alternatif dari konflik yang ada, sekalipun kualitas dalam penyelesaiannya kurang berkualitas, karena keselarasan dari mengalah tidak bertumpu kepada kesepahaman, namun hanya berprinsip kepada keinginan untuk tidak memperpanjang dan memperlebar ruang lingkup dampak yang akan terjadi. Mengalah tidak hanya bermakna sempit, dengan tidak membiarkan lawan konflik melakukan semena-mena, akan tetapi memberikan ruang yang lebih besar kepada pihak lain untuk mendapatkan tujuannya.

Ketiga, problem solving (pemecahan masalah). Setiap jalan pasti ada ujungnya, setiap keinginan pasti ada tujuannya, setiap tujuan pasti ada arahnya, dan setiap arah pasti ada petunjuknya, dan setiap masalah pasti ada pemecahan atau solusinya. Kaidah problem solving memberikan gambaran terhadap berbagai persoalan yang dihadapi adalah bagian hidup yang tidak dapat dipisahkan dalam kehidupan manusia yang saling membutuhkan dengan tujuan masing-masing sesuai dengan harapan dan keinginannya. Konsep konflik memberikan pembelajaran bagi seluruh manusia untuk bersikap adil, bijaksana, dewasa, dan bertatakrama, termasuk dalam hal konflik yang dialami, hendaknya dilakukan penyelesaian secara bijaksana. Dalam hal 
ini, strategi penyelesaian dengan problem solving memberikan ruang untuk berkomunikasi antara pihak yang berkonflik dengan mencari sumber masalah yang dihadapi secara bersama, tentu hal ini dibutuhkan pihak ketiga dalam perundingannya. Kemudian, dicarikan alternatif pemecahan dengan berbagai pertimbangan dengan penjelasan terhadap problematika yang dihadapi dengan melihat aspek kelemahan dan kekuatan dalam pemecahannya serta aspek saling menerima dari solusi yang ditawarkan. Komunikasi menjadi bagian terpenting dalam penyelesaian konflik dengan problem solving ini, baiknya komunikasi yang dilakukan oleh pihak ketiga akan berdampak positif terhadap penyelesaiannya, sehingga dapat diterima oleh semua pihak dengan penyelesaian secara kualitas dan proporsionalitas.

Keempat, with drawing (menarik diri). Konflik terjadi karena ketidaksepahaman antar individu atau kelompok yang berakibat terjadinya bentrok psikis atau fisik dengan berbagai pola. Menarik diri merupakan bagian dari solusi pemecahan konflik yang ada dengan menghindari keberadaan konflik dari situasi yang ada, artinya meninggalkan keberadaan konflik yang terjadi agar tidak terjadi sebuah konflik yang lebih besar. Prinsip ini dilakukan untuk memberikan pelajaran dengan tidak menghiraukan keberadaan sebuah konflik terhadap individu yang mengakibatkan keberadaan konflik tersebut, sehingga dengan tidak dihiraukannya indikator konflik dengan pergi dari keberadaannya, dengan sendirinya individu yang membuat konflik akan sadar dengan sendirinya, bahwa individu yang dikonflikan tidak mengindahkannya.

Kelima, incation (diam). Tidak melakukan sesuatu apapun dalam keadaan konflik mungkin lebih baik untuk menghindari sumber-sumber konflik yang lebih fatal. problem solving bagian terpenting dari strategi penyelesaian konflik didalam ranah diam dalam konflik. Diam bagian yang biasa dilakukan oleh individu atau kelompok dalam penyelesaian suatu konflik yang ada, dengan diam, maka ada faktor lain yang mempengaruhi suatu 
konflik untuk diselesaikan, ketika individu yang sedang berkonflik diam, maka disitu muncul sebuah strategi problem solving dengan memberikan pandangan secara konkrit tentang problematika yang dihadapi untuk diselesaikan secara bersama dengan pikiran yang jernih dan komunikasi yang baik, sehingga ada pencapaian yang diharapkan berasama dan konsistensi dari sebuah keinginan untuk tidak menimbulkan sebuah neraca konflik dikemudian hari.

Pemahaman konflik dengan menggunakan kerangka teori konflik fungsional dan teori perilaku dapat menjadi dasar dalam memberi kerangka penyelesaian konflik. Mengikuti pandangan Burton (1990) dalam Kolopaking, dkk ${ }^{9}$. Bahwa penyelesaian konflik dapat dilakukan dalam 3 (tiga) bentuk berbeda. Pertama, melalui manajemen untuk menemukan alternatif jalan keluar sebuah perselisihan (by alternative dispute resolution) agar dapat menampung atau membatasi konflik. Manajemen konflik perlu dilakukan dalam pembatasan konflik yang lebih luas, artinya bahwa keberadaan konflik dalam masyarakat perlu dimanajemen dengan baik, sehingga tidak melebar kepada konflik yang lainnya. mencari alternatif solusi terhadap keberadaan konflik menjadi bagian pemecahannya, sehingga alternatif itu menjadi sebuah kesadaran yang harus dilakukan bersama-sama antara pihak yang berkonflik dengan consensus memandang secara positif. Manajemen konflik dilakukan untuk memberikan ruang penyelesaian secara konsepsi dan prinsip dasar konflik yang ada, sehingga tatanan yang sudah ada menjadi bagian terpenting dalam pengelolaan konflik itu sendiri. Jika konflik dimanajemen dengan baik dengan tatanan masyarakat yang ada dan kesadaran bersama dengan berbagai konskuensi yang akan dialami, maka konflik akan reda dengan melakukan sebuah introspeksi diri dari pihak-pihak terkait. Oleh Karena itu perlu diadakan sebuah

${ }^{9}$ Ibid. Kolopaking, dkk. “Jejaring Sosial .", hal. 190-191. 
interaksi secara sadar tentang sesuatu yang menjadi sumber konflik dengan pola yang realistis dan rasional.

Kedua, adalah penyelesaian konflik (settlement) dengan menggunakan proses yang bersandar pada wewenang dan hukum yang dapat dipaksakan oleh kelompok elit. Pertikaian dalam masyarakat sebagai sekelompok orang yang dikuasai dan menguasai menjadi bagian terpenting dari penguasa untuk melerai terjadinya konflik. Penguasa sebagai yang menguasai mempunyai peran penting dalam penyelesaian konflik yang berada didaearah kekuasaannya. Penyelesaian konflik seperti ini membutuhkan konsep pemikiran dari para elit penguasa dalam pemecahannya, sehingga keberadaan penguasa menjadi sentralistik dengan memberikan solusi-solusi alternatif terhadap konflik yang ada. Hal ini dilakukan dengan konsep-konsep hukum yang melekat dalam tatanan masyarakat itu sendiri, baik secara hukum nasional, agama, maupun hukum adat. Penyelesaian konflik secara hirarki lebih elok jika dikelola dengan penekanan terhadap hukum yang berlaku, karena didalam sebuah hukum yang melingkupinya ada sebuah sanksi yang memaksa seseorang untuk mentaati berbagai ketentuan hukum, karena apapun bentuk konflik yang ada merupakan sebuah konsorium negatif dalam kehidupan masyarakat dan menjadi pertentangan dalam hukum kemasyarakatan.

Ketiga adalah melakukan resolusi konflik. Sumber konflik menjadi pertimbangan-pertimbangan dalam penyelesaian dengan analisis rasioanl empiris dalam pengelolaannya, pertimbanganpertimbangan itu melihat dari individu dan kelompok masyarakat yang berkonflik, mislanya indentitas, kelompok, pengakuan, dan pelbagai perubahan untuk memenuhi kebutuhannya. Resolusi konflik menjadi bagian terpenting dalam penyelesaian konflik yang beskala besar, namun tidak menutup kemungkinan bagi konflik antar individu. penyelesaian dengan mencari sumber konflik dengan menganalisi indikator-indikator konflik yang ada, kemudian dipecahkan dengan konsep-konsep pemikiran yang 
realistis dan independensi merupakan sebuah langkah konkrit dalam pemahamannya, sehingga ketika sumber konflik sudah ditemukan, maka solusi yang didahrapkan juga dapat dihadirkan dengan persepsi bahwa solusi itu yang terbaik dalam penanganannya. konsepsi ini memberikan pemikiran secara ilmiah dengan berbagai konsekuensi yang dihadapi, akan tetapi ini menjadi lebih baik untuk tidak mengulang konflik yang ada.

\section{Interkoneksi Hukum Islam Terhadap Teori Konflik}

Arkoun dalam Syaukani ${ }^{10}$, mengatakan bahwa pembentukan hukum islam dalam asas teori tertinggi (asâs al-siyâdah al-'ulyâ) dapat diklasifikasikan pada empat persoalan. Pertama, wewenang agama. Agama sebagai pondasi dasar umat islam mempunyai resolusi yang sangat kental dengan sakralisasi kehidupan manusia, sebagai pandangan dan peta tujuan manusia dalam mengaplikasikan konsep-konsep yang telah diwahyukan oleh Allah. swt. kepada hamba-Nya dengan berbagai anjuran dan larangan yang harus diimplementasikan dalalm kehidupan sosialnya sebagai paradigma yang melekat dan membentuk karakter manusia menjadi lebih baik. Secara prinsip agama adalah berasal dari dua kata yang terpisah, yaitu "a" bemakna tidak, dan "gama" mempunyai arti kacau. Artinya bahwa, agama adalah tidak menjadikan kacau dalam kehidupan ummatnya, agama menjadi panduan hidup dan pedoman kehidupan untuk berlaku baik, bijaksana, tolong menolong, kejujuran, dan prinsip-prinsip kebaikan yang diajarkan didalamnya ${ }^{11}$. Agama tidak hanya menjadi simbol disposisi kehidupan sebagai tanda bahwa manusia itu beragama dengan kepentingan-kepentingan jiwa yang melekat dalam dirinya. Agama harus diaplikasikan dalam kehidupannya dengan konsekuensi mematuhi segala ketentuan hukum yang mengatur didalamnya dengan cara "iqra". Membaca

${ }^{10}$ Imam Syaukani, "Hakikat Hukum Islam:Antara Divine Law Dan ManMade Law”. Ulumuddin, Volume VI, Tahun IV, Januari-Juni 2010, hal. 500.

${ }^{11}$ Ibid. Sari, "Jaring pengaman. ," h. 24 
dalam prinsip iqra' bukan dimaknai hanya membaca terhadap keberadaan agamanya, akan tetapi membaca, mempunyai persepsi yang sangat luas dengan mengetahui, memikirkan, memahami, meneliti, dan mengaplikasi dalam kehidupan seharihari sesuai dengan tingkat pemahaman dan pengaplikasiannya, sehingga konektivitas jiwa dalam pergulatan agama menjadi lebih erat kaitannya dengan keberadaan Tuhannya yang memberikan hukum bagi umat beragama.

Kedua, posisi al-Qur'an sebagai sumber eksplisit normanorma yang didasari oleh wewenang Ilahi. Alquran merupakan kitab suci yang disakralkan dalam perkembangannya sebagai sebuah ajaran yang menjadi hukum bagi umat islam. Alquran menjadi bagian terpenting dalam kehidupan umat islam sebagai pedoman dan tuntutan hidup keagamaan dengan segala perintah dan larangan-Nya, sebagai dasar dalam memberikan solusi setiap problematika kehidupan, sebagai obat dalam kesakitan, sebagai penenang dalam kekacauan, sebagai pondasi dalam tatanan sosial umat manusia, sebagai hakim dalam perilaku manusia, sebagai tempat berteduh ketika kepanasan, sebagai payung disaat hujan, dan kemanfaatan lain yang ada dalalm kehidupan manusia. Disadari atau tidak, segala tuntutan hidup manusia dijelaskan dalam kitabullah sebagai wewenang Allah dalam mengajarkan kebaikan dan ketaatan manusia kepada-Nya. Allah sebagai pencipta manusia untuk menjadi khalifah di muka bumi menjadi sebuah keharusan atas anugerah yang telah diberikan dengan rahmat dan rahim bagi seluruh ummat manusia agar berpegang kepada prinsip-prinsip ajaran Al-Quran. Tonggak sejarah Alquran memberikan eksplorasi manusia dalam mengahadapi segala tantangan zaman dengan berbagai konsepsi yang berada didalamNya. Kewenangan Allah dalam Alquran mengantarkan kepada suatu kebaikan dalam mengetahui aspek-aspek cipataan-Nya sebagai kemanfaatan bagi manusia secara universal.

Ketiga, sunnah dan wewenang Nabi. Alquran memberikan penjelasan secaraobyektif dengan konsep substansi pemahaman 
yang tidak menjelaskan ketentuan teknis. Hadis menjadi bagian teknisi dari Alquran yang mempunyai integrasi yang sangat tinggi dalam memahami makna substansi Al-Quran. Hadis sebagai sunnah Rasulullah dari segala aspek kehidupan yang dilatarbelakangi oleh Al-Quran, menggambarkan secara ekperimental tentang makna kehidupan yang diajarkan oleh Alquran sebagai wewenang Nabi dalam mengajarkan, menjelaskan dan mengarahkan umat manusia untuk bersikap dan bersifat eksplisit dalam mengamalkan komponen-komponen Alquran sebagai pedoman hidup. Sunnah memberikan ruang bagi umat untuk melakukan kebaikan-kebaikan yang tidak dijelaskan secara jelas oleh Alquran sebagai tuntutan manusia dalam menghadapi segala zaman yang semakin kompleks terhadap problematika kehidupan yang semakin luas. As-Sunnah menjadi pendamping Alquran dalam pengamalan terhadap nilai-nilai islam secara kaffah dan professional terhadap seluruh elemen manusia yang memberikan pengertian tentang substansi Alquran secara menyeluruh dan konseptual. Pandangan sunnah adalah segala bentuk perbuatan yang dilakukan oleh Rasulullah dengan segala wewenang yang dimiliki-Nya dan kearifan yang diajarkan untuk mengantarkan hambanya menjadi manusia yang insane kamil dengan janji Allah dalam Al-Qurannya yaitu di hari akhirat kelak sebagai reward yang diterimanya yaitu surga dengan kehidupan yang kekal didalamnya. Sunnah menjadi bagian hukum dalam islam sebagai pedoman kedua setelah Al-Quran, yang mengajarkan manusia untuk mematuhi segala ketentuan yang ada didalamnya dengan tidak menghilangkan nilai-nilai qurani. Sunnah memberikan penjelasan hukum tentang peraturan-peraturan yang ada didalam Alquran sebagai pijakan keselamatan dan kesadaran bagi manusia untuk berbuat sesuai dengan tuntutan ajaran islam. Keberadaannya tidak bisa dilepaskan dari tuntutan Alquran sebagai pedoman dasar manusia, dan sunnah adalah penyeimbang kehidupan dengan ketentuan-ketentuan pada zamannya. 
Keempat, prosedur pengembangan oleh manusia dan kepatuhan kepada wewenang meliputi ijmâ' (konsensus umat), ijtihad dan cara-cara pokoknya: qiyâs, istihsân, ikhtilâf (divergensi). Kehidupan manusia mengalami berbagai perubahanperubahan yang meliputi zamannya, dengan kata lain setiap manusia mempunyai zamannya masing-masing sesuai dengan perubahana yang ada. Perubahan zaman tidak bisa dilepaskan dari masing-masing peran manusia dalam kehidupannya, dari perubahan secara revoluioner, evolusioner dan reforamasi hingga transisi manusia dalam berbagai perilaku kehidupan yang melekat pada masanya. Tuntutan hukum islam yang semakin kompleks dalam berbagai perkembangan kehidupan manusia memberikan arahan yang compatible dalam mematuhi segala bentuk hukum keimanan. Ada beberapa ketentuan hukum dalam islam yang tidak dijelaskan secara implisit terhadap pola kehidupan yang ada, hal ini memberikan wewenang terhadap pengemban amanah Rasulullah dalam memberikan arahan dan penjelasan tentang makna hukum islam yang kurang dipahami sebagai suatu konsensus realistis kehidupan. Ijma', qiyas, ikhtihsan, ikhtilaf (devegerasi) sebagai panduan keempat dalam menuntun hukum islam sebagai ikhtiar kebaikan dalam keadaan zaman yang menginginkan suatu hukum yang jelas dengan segala wewenangnya. Hal ini menunjukkan adanya campur tangan suatu nalar yang bergerak dalam korpus yang terbatas (al-Qur'an dan hadits) diarahkan pada pemahaman yang transendental (Ilâhîyah).

Hukum islam mempunyai beberapa prinsip dalam penerapannya, antara Fiqih dan Syari'ah merupakan dua hukum yang tidak dapat dipisahkan dalam hukum islam. Najitamah ${ }^{12}$, mengungkapkan bahwa perbedaannya adalah seperti yang disampaikan oleh Abu Ameenah dengan tiga perbedaan, yaitu:

${ }^{12}$ Fikria Najitama. "Sejarah Pergumulan Hukum Islam dan Budaya Serta Implikasinya Bagi Pembangunan Hukum Islam Khas Indonesia”. Al-Mawarid, Edisi XVII, Tahun 2007, h. 104. 
Pertama, Syari'ah merupakan hukum yang diwahyukan Allah yang terdapat dalam al-Qur'an dan sunah. Sebagai pedoman dan prinsip umat islam dalam perjalan hidup didunia ini, Alquran dan Sunnah menjadi tuntunan yang diaplikasikan dalam kehidupannya, dalam kehidupan kemasyarakatan mengajarkan manusia untuk berbuat baik antar sesama dengan prinsip-prinsip keadilan dan kebijaksanaan dengan penekanan terhadap nilainilai agama dengan tidak membuat sebuah kekacauan dalam bermasyarakat. Oleh karena itu, Alquran dan sunnah memberikan pemahaman secara universal dalam kehidupan umat beragama, bagaimana hidup antar sesame mahluk Allah dengan hubunganhubungan yang melekat dalam kodratnya sebagai manusia, bagaimana hubungan antara manusia dengna tuhannya, dan bagaimana manusia menjadi pemimpin didunia dengan segala tanggung jawab yang melekat dalam dirinya. Sehingga keberadaan Alquran dan sunnah menjadi bagian terpenting dalam penyelesaian berbagai permasalahan dan problematika kehidupan manusia, hal ini juga bisa diberlakukan kedalam konsep konflik yang ada didalam kehidupan masyarakat yang semakin kompleks dengan berbagai globalisasi yang mengikutinya. Alquran menawarkan berbagai manajemen dan resolusi dalam problemtaika masyarakat seperti konflik. Konsepsi syariah dalam pengaturan terhadap manusia menjadi penting dengan eksistensi syariah bagi umat manusia menjalani roda kehidupan. Syariah mengajarkan kebaikan-kebaikan yang tidak pernah berubah dan tidak bisa dirubah dengan cara apapun, karena keberadaannya menyesuaikan dengna zaman dan kondisi yang ada. Sesuatu yang baik menurut syariah, maka baik untuk dilakukan sebagai hukum bagi manusia dalam melakukan sesuatu, begitu juga sebaliknya. Permanennya sebuah konsep hukum islam memberikan konsistensi dalam penerapannya, sehingga perlakuannya juga menjadi akurasi dan keyakinan yang menonjolkan nilai-nilai dan norma kehidupan yang hakiki. Semenata Fiqih adalah sebuah teknis dalam melakukan syariah 
yang merespon situasi-situasi tertentu yang tidak secara langsung dibahas dalam hukum syari'ah. Fiqih berjalan sesuai dengan kebutuhan zaman dengan berbagai paradigma dan perilaku manusia dalam kehidupannya, fiqih memberikan gambara secara lebih detail tentang pola kemasyarakatan dengan tetap merujuk sepenuhnya kepada syariah. Artinya bahwa, fiqih menjalankan perintah-perintah syariah dengan pola penyesuaian kehidupan masyarakat yang ada.

Allah, dalam Firman-Nya, yang artinya, Hai sekalian manusia, bertakwalah kepada Tuhan-mu yang telah menciptakan kamu dari seorang diri, dan dari padanya Allah menciptakan isterinya; dan dari pada keduanya Allah memperkembang biakkan laki-laki dan perempuan yang banyak. dan bertakwalah kepada Allah yang dengan (mempergunakan) nama-Nya kamu saling meminta satu sama lain, dan (peliharalah) hubungan silaturrahim. Sesungguhnya Allah selalu menjaga dan mengawasi kamu ${ }^{13}$. Dalam ayat ini Allah menganjurkan sebuah kewajiban bagi ummat manusia untuk memelihara hubungan antara manusia dengan manusia dengan saling tolong menolong antara sesama. Allah memberikan penguatan, bahwa dengan ketakwaan seorang hamba terhadapnya dan jalinan silaturrahmi, maka akan dihindarkan dirinya dari keberadaan sebuah pertikaian atau konflik. Lebih lanjut, Allah berfirman yang artinya, Hai manusia, Sesungguhnya Kami menciptakan kamu dari seorang laki-laki dan seorang perempuan dan menjadikan kamu berbangsa-bangsa dan bersuku-suku supaya kamu saling kenal-mengenal. Sesungguhnya orang yang paling mulia diantara kamu disisi Allah ialah orang yang paling taqwa diantara kamu. Sesungguhnya Allah Maha mengetahui lagi Maha Mengenal ${ }^{14}$.

${ }^{13}$ Q.S. An Nisaa' (4) : 1

${ }^{14}$ Q.S. Al-Hujurat (49): 13 
Soejoeti dalam Sayukani ${ }^{15}$, memberikan penjelasan bahwa konsep hukum menurut ahli fiqih pada dasarnya terletak di atas ide, hukum itu bersifat keagamaan. Agama sebagai pedoman ummat manusia dalam mengarungi kehidupan kemasyarakatan yang menjadi idelogi dan keyakinan yang melekat dalam diri setiap individu sebagai sebuah prinsip yang dilakukan dengan segala konskuensi yang diterimanya menjadi bagian yang amat penting dalam perjalanannya di muka bumi ini. Islam, dalam hal ini bukan hanya sebatas agama dengan hukum-hukum yang sudah ditentukan dan pengamalan-pengamalan yang dianjurkan, akan tetapi islam adalah sebuah value yang mempunyai karakteristik dan konsepsi hukum yang menuntut seluruh ummatnya untuk mengembangkan prinsip-prinsip yang ada didalam Alquran sebagai kitab suci dengan penjelasan-penjelasan dalam Al-Hadist. Hukum dalam islam sejak periode paling awal sejarah Islam, telah dipandang sebagai bagian dari syari'ah. Adapun syari'ah sebagaimana telah dijelaskan diatas, adalah pola tingkah laku manusia yang diatur oleh Allah SWT.

Apabila dikatakan kepada mereka: "Marilah kamu (tunduk) kepada hukum yang Allah telah turunkan dan kepada hukum Rasul", niscaya kamu lihat orang-orang munafik menghalangi (manusia) dengan sekuat-kuatnya dari (mendekati) kamu ${ }^{16}$. Dalam konteks ini adalah hukum Allah yang sudah dimaktubkan dalam Alquran dan tunduk kepada As-Sunnah yang diimplementasikan oleh Rasulullan dalam kehidupan bermasyarakat, termasuk dalam hal ini adalah ketundukannya dalam hal penyelesaian berbagai persoalan-persoalan hidup bagi dirinya sendiri atau bagi kelompok masyarakatnya.

Konteks Negara Indonesia, hukum islam mempunyai ciri khas dalam penerapannya, dari kedua hukum yang melekat diatas menjadi pembentukan hukum islam yang ada, yaitu: Pertama,

${ }^{15}$ Ibid. Sayukani. “Hakikat Hukum...................", h. 498.
${ }^{16}$ Q.S. An Nisa (4): 61 
kontekstual. Islam sebagai kekuatan agama yang menerapkan prinsip hukum sesuai dengan situasi dan kondisi zaman dan tempat dimana keberadaannya. menjadi sebuah keniscayaan untuk melakukan ijtihad dan berbagai penafsiran dari syariah dan fiqih yang sudah ada sebagai pengembangan dan adaptasi hukum islam, sehingga islam dapat direlevansikan menjadi salih li kulli zaman wa makan. Kedua, menghargai tradisi lokal. Kebudayaan islam mempunyai cara dan pola tersendiri dalam menghargai satu sama lain, termasuk didalam menghormati berbagai budaya lokal dalam suatu bangsa. Islam di Indonesia tidak bisa dilepaskan dari kebudayaan-kebudayaan sebelum islam, dari berbagai sejarah yang ditorehkan oleh para mujahidin islam dalam penyebaran agama islam di Indonesia, bagaimana para waliyullah (wali songo) mengembangkan nilai-nilai islam masuk dalam kebudayaan jawa dengan mengubah pola pikir dan karakter masyarakat jawa dengan memasukkan nilai-nilai islam kedalamnya, sehingga islam dapat diterima sebagai sebuah keyakinan agama bagi mereka. Budaya lokal bangsa Indonesia menjadi bagian dari perjalanan islam di nusantara, tinggal bagaiman mengaplikasikan kedalam kehidupan sehari-hari dengan memegang teguh kepada syariah (Alquran dan Al-Hadist) ${ }^{17}$

\section{PENUTUP}

Teori konflik memberikan pandangan kepada manusia sebagai koneksi terhadap perilaku dan kehidupan dalam bermasyarakat. Masyarakat mempunyai peran dan ketentuanketentuan dalam menjalankan sebuah kehidupan dilingkungannya, dengan berbagai tujuan dan harapan yang menjadi capaiannya. Konflik dalam kehidupan masyarakat tidak dapat dihindarkan dengan berbagai stigma yang ada didalamnya dengan berbagai gesekan-gesekan dan benturan-benturan yang muncul dari berbagai faktor kehidupan manusia. Keberadaan konflik mengimplikasikan terhadap sebuah perubahan dan

\footnotetext{
${ }^{17}$ Ibid. Najitama. “Sejarah Pergumulan.................”, h. 110.
} 
ketidaksepahaman masyarakat atau individu dalam menjalankan konsepsinya sebagai manusia. Pendewasaan masyarakat dituntut dalam penyelesaian terhadap konflik yang muncul dengan berbagai strategi dan konsep yang ada.

Pertimbangan-pertimbangan dalam penyelesaian konflik di tengah-tengah masyarakat atau individu diperlukan sebuah pendekatan hukum yang berdampak terhadap penyelesaian secara professional dan proporsional sesuai dengna kebutuhan dan harapan secara bersama. Islam sebagai agama menjadikan konsepsi pemikiran melalui Alquran dan Hadis dalam penerapan terhadap penyelesaian konflik. Ketentuan Allah terhadap hambaNya untuk saling menghormati dan menghargai satu sama lain, terhadap individu dengan individu, kelompok dengan kelompok, atau individu dengan kelompok, atau sebaliknya.

\section{DAFTAR PUSTAKA}

Andik Wahyun Muqoyyiidin, "Potret Konflik Bernuansa Agama di Indonesia; Signifikansi Model Resolusi Berbasis Teologi Transformatif", Analisis, Volume XII, Nomor 2, Desember Tahun 2012, h. 315-340.

Defi Arini Rahayuningtias dan Arief Sudrajat, "Konflik dan Pola Defiance Warga Perwira di Komplek Militer", Jurnal Paradigma, Volume 01, Nomor 03, Tahun 2013, h. 1-7.

Den G. Pruit dan Jeffry Z. Rubbin, Teori konflik Sosial, ter. Helly P. Soejtipto dan Sri Mulyantini Soetjipto, (cet. III; Yogyakarta: Pustaka Pelajar, 2011).

Departemen Agama Republik Indonesia, Alquran dan Terjemahan, (Jakarta: Departemen Agama Republik Indonesia, 1989).

Fikria Najitama. "Sejarah Pergumulan Hukum Islam dan Budaya Serta Implikasinya Bagi Pembangunan Hukum Islam Khas Indonesia". Al-Mawarid, Edisi XVII, Tahun 2007, h. 101-114. 
Imam Sayukani. "Hakikat Hukum Islam: Antara Divine Law Dan Man-Made Law. Ulumuddin, Volume VI, Tahun IV, JanuariJuni 2010, h. 498-505.

Lala Mulyowibowo Kolopaking, Djuara Pangihutan Lubis, August Ernest Pattiselanno, "Jejaring Sosial dan Resolusi Konflik Masyarakat di Pedesaan (Kasus di Pulau Saparua Provinsi Maluku)", Jurnal Pertanian Indonesia, Volume 12, Nomor 3, Desember 2007, h. 188-203.

Ramadhanita Mustika Sari, "Jaring pengaman Pencegah Konflik: Kasus Masyarakat OKU Timur”, Tesis, (Jakarta: Sekolah Pascasarjana, Universitas Islam Negeri, 2011). 